\title{
A Genetic Shift in the Virus Strains that Cause Mosaic in Louisiana Sugarcane
}

\author{
M. P. Grisham and Y.-B. Pan, United States Department of Agriculture-Agricultural Research Service, Southern \\ Regional Research Center, Sugarcane Research Laboratory, Houma, LA 70360
}

\begin{abstract}
Grisham, M. P., and Pan, Y.-B. 2007. A genetic shift in the virus strains that cause mosaic in Louisiana sugarcane. Plant Dis. 91:453-458.

Leaf samples from 693 sugarcane plants showing mosaic symptoms were collected in 2001, 2002, and 2003 at 12 locations within the Louisiana sugarcane industry. Virus isolates associated with the diseased plants were identified using reverse-transcriptase polymerase chain reaction (RT-PCR) to distinguish between Sugarcane mosaic virus (SCMV) and Sorghum mosaic virus (SrMV). No SCMV strain was associated with any diseased plant collected during the survey. RT-PCR-based restriction fragment length polymorphism (RFLP) analysis showed that SrMV strains $\mathrm{I}, \mathrm{H}$, and $\mathrm{M}$ were associated with 67,10 , and $2 \%$ of the plants with mosaic symptoms, respectively. In previous surveys conducted between 1978 and 1995, over $90 \%$ of the plants sampled were infected with SrMV strain $\mathrm{H}$. The remaining plants mostly were infected with SrMV strain I, except for an occasional sample with SrMV strain M. RT-PCR showed that approximately $13 \%$ of the samples collected between 2001 and 2003 were infected with SrMV, but the RFLP banding pattern did not match any described strain. Twelve plants were co-infected by two SrMV strains and two plants by three SrMV strains. No RT-PCR product was produced by either the SCMV- or the SrMV-specific RT-PCR primer set for $8 \%$ of the plants showing mosaic symptoms, suggesting that another virus may cause sugarcane mosaic in Louisiana.
\end{abstract}

Mosaic caused by Sugarcane mosaic virus (SCMV) (family: Potyviridae; genus: Potyvirus) contributed to the near-collapse of the sugarcane industry in Louisiana near the beginning of the 20th century (1). To control this disease, interspecific Saccharum hybrids tolerant to mosaic were imported from Java to replace the noble canes (Saccharum officinarum L.) that were being grown at the time $(2,7,8,11)$. The Java cultivars were selected under tropical conditions and were tolerant, but not resistant, to mosaic. Therefore, a breeding program was established to develop mosaicresistant cultivars that would be adapted to Louisiana conditions (5). Resistance to mosaic remains a major selection criterion in the sugarcane breeding program.

Summers and coworkers (18) were the first to use differential hosts to identify strains of the virus causing mosaic. A set of differential hosts and strain descriptions

Corresponding author: M. P. Grisham E-mail: mgrisham@srrc.ars.usda.gov

Mention of a trademark, proprietary product, or vendor does not constitute a guarantee or warranty of the product by the United States Department of Agriculture and does not imply its approval to the exclusion of other products or vendors that may also be suitable.

Accepted for publication 24 October 2006.

doi:10.1094/PDIS-91-4-0453

This article is in the public domain and not copyrightable. It may be freely reprinted with customary crediting of the source. The American Phytopathological Society, 2007. proposed by Abbott and Tippett (2) and later modified to provide descriptions of more recently discovered strains $(10,20)$ have been widely used. Strains of virus causing mosaic in Louisiana have been monitored since the 1930s $(5,7)$. Various strains emerged and became dominant in the Louisiana sugarcane industry at different times, often associated with the major cultivars under cultivation (11). Strain E is believed to have infected the early noble canes and the early hybrid cultivars. Strain $\mathrm{D}$ appeared with the introduction of the Saccharum hybrids from Java. Between 1930 and 1950, strains B and D were the most commonly recovered strains from plants expressing mosaic symptoms when cvs. Co 281 and Co 290 were the most commonly grown cultivars. Strain D became dominant when Co 281 was no longer grown. Sporadic outbreaks of strain A were reported during the 1940s and 1950s (11).

Strains H, I, and M appeared in Louisiana in 1956 (2), 1966 (20), and 1973 (10), respectively, and originally were classified as strains of SCMV. Later taxonomic studies based on amino acid and nucleic acid sequences led to the formation of the Potyvirus species Sorghum mosaic virus (SrMV), containing strains $\mathrm{H}$, I, and M $(14,16,21)$. Strain H became the dominant strain soon after its discovery in 1956 and in subsequent surveys conducted annually until 1993 (5,7). Strains I and M were the only other strains recovered between 1978 and 1993 (7). The highest levels of strain I recovery corresponded to an area of the state where cv. NCo 310 was widely grown and, with the decline of NCo 310 , the frequency of recovering strain I also declined $(5,7)$. Although strain I was recovered from as many as $75 \%$ of the $\mathrm{NCo}$ 310 samples during this period, other strains were recovered from NCo 310 and strain I was recovered from other cultivars (7). A similar relationship also was suggested for the occurrence of strain $\mathrm{M}$ and the growing of cv. CP 79-318 (7). Thus, the virus strains that have been reported to cause mosaic on sugarcane in Louisiana have been strains A, B, D, and E of SCMV and strains $\mathrm{H}, \mathrm{I}$, and $\mathrm{M}$ of SrMV.

In surveys conducted between 1985 and 1995 across Louisiana (7; unpublished), strain $\mathrm{H}$ of SrMV was recovered consistently from over $90 \%$ of the plants expressing mosaic symptoms, and no new strains were identified. Consequently, the decision was made to discontinue the annual mosaic surveys. Several observations, however, suggested a need to resume the identification of strains causing mosaic in Louisiana. Promising cultivars were eliminated at the final stages of the cultivar development program because of mosaic susceptibility even though they had been exposed to natural infection for more than 10 years under conditions that had resulted in the elimination of other candidate cultivars. Atypical symptoms also were being reported from susceptible cultivars. Among the possible explanations for these unexpected observations was a genetic change within the SrMV population or the appearance of a new virus pathogen. Furthermore, the Louisiana sugarcane industry had become vulnerable to a new, more aggressive biotype of an endemic pathogen or the introduction of an exotic pathogen because of its dependency on a single cultivar, LCP 85-384, which occupied 78\% of the planted area in 2001 and expanded to $91 \%$ in 2004 (13).

Serological-based assays (11) and reverse-transcriptase polymerase chain reaction (RT-PCR) protocols (17) currently are available to identify SCMV and SrMV; however, until 1997, the only reported method of distinguishing the strains of SCMV and SrMV was to inoculate differential hosts with sap extracted from the infected plant and observe plants for the development of symptoms characteristic of the different virus strains $(2,10,20)$. However, the use of host differentials was time consuming and labor intensive (7). In 1997, Yang and Mirkov (21) reported the development of an RT-PCR-based restriction fragment length polymorphism 
(RFLP) analysis protocol to distinguish between SCMV and SrMV and the strains within each. A pair of RT-PCR primers (21) was used to detect SCMV and another pair to detect SrMV. The RT-PCR products then were subjected to an RFLP analysis for differentiating individual strains. The availability of the RT-PCR-based RFLP protocol provided a practical and efficient method to identify virus strains causing mosaic. The objective of this study was to identify by the RT-PCR-based RFLP protocol (21) the strains of viruses causing mosaic in field-grown Louisiana sugarcane plants during the 2001, 2002, and 2003 growing seasons.

\section{MATERIALS AND METHODS}

Sample collection. Leaves from sugarcane plants with mosaic symptoms were collected from three, eight, and nine field locations in 2001, 2002, and 2003, respectively (Table 1). The youngest leaf with a visible dewlap (the collar at the leaf blade and sheath junction) was collected from the plants expressing mosaic symptoms. The leaves were stored at $-20^{\circ} \mathrm{C}$ until strain identification was performed.

Most leaf samples were collected from plots in sugarcane-breeding-field trials located on producer farms that included advanced candidate cultivars and commercial check cultivars. The trials were conducted under plantation environment and regular cultural practices. Because of the perennial nature of sugarcane, the trials were harvested annually for 3 to 4 years. The Terrebonne Parish location in 2001 was the United States Department of Agriculture-Agricultural Research Service Sugarcane Research Laboratory Farm, and the Iberville Parish location in 2002 and 2003 was the Louisiana State University Sugarcane Research Farm (Table 1). Among sugarcane cultivars recommended for planting in Louisiana, three (LCP 85384, HoCP 96-540, and Ho 91-555) are resistant, one (HoCP 85-845) is moderately resistant, and one (CP 70-321) is moderately susceptible to mosaic; therefore, mosaic infection within the commercial sugarcane crop is rare. Because of the high level of resistance among the cultivars, the only leaf samples from commercially grown sugarcane were those collected in 2002 from five fields in Assumption Parish. Sugarcane plants with mosaic symptoms were sampled in four fields of a mosaic-susceptible cultivar, $\mathrm{CP}$ 65-357, that is no longer recommended for cultivation, and in one field of a currently recommended, moderately resistant cultivar, HoCP 85-845 (Table 1).

In all, 693 leaf samples were collected. Of these, 35 leaf samples from plants showing mosaic symptoms were collected at three locations in 2001, 355 samples were collected at eight locations in 2002, and 303 samples were collected at nine locations in 2003. In the 2002 and 2003 surveys, leaves were collected from five mosaic-affected plants of a cultivar within a sampled experimental plot or field, except in a few experimental plots where there were fewer than five plants expressing mosaic symptoms. The number of plots or fields and the number of cultivars sampled at each location are shown in Table 1. Cultivars that showed mosaic symptoms differed among locations. Only a few cultivars were present at several locations, whereas most cultivars were present at only one or a few locations. Sixty cultivars were sampled in the course of the 3-year survey. Leaf samples were collected at six locations in both 2002 and 2003 (St. James Parish nursery and outfield test, Iberia Parish outfield trial, Iberville Parish research farm, Lafourche Parish outfield trial, and Terrebonne Parish outfield trial). Of the 41 plots sampled at these locations in 2003, 27 also were sampled in 2002. Because individual plants sampled were not marked, the leaves sampled in the ratoon crop might not have been from the same plant.

Diagnosis. Diagnostic controls were established by performing RT-PCR-based RFLP analysis on plants previously identified with the differential hosts as being infected with strains A, B, and D of SCMV and strains $\mathrm{H}, \mathrm{I}$, and $\mathrm{M}$ of SrMV. Tissue from these plants became the positive controls when conducting the diagnosis of unknown samples. Total RNA was extracted from approximately $200 \mathrm{mg}$ of midrib tissue from sugarcane leaves expressing mosaic symptoms. The tissue was

Table 1. Incidence of virus strains causing mosaic on sugarcane in Louisiana

\begin{tabular}{|c|c|c|c|c|c|c|c|c|c|c|c|}
\hline \multirow[b]{2}{*}{ Year } & \multicolumn{2}{|c|}{ Location } & \multicolumn{4}{|c|}{ Number of (\% in parentheses) } & \multicolumn{4}{|c|}{ Incidence (\% in parentheses $)^{a}$} & \multirow[b]{2}{*}{ Neg. ${ }^{d}$} \\
\hline & Parish & Type & Samples & Plots or fields & Cultivars & Pos. $^{\text {b }}$ & $\mathbf{H}$ & $\mathbf{I}$ & $\mathbf{M}$ & Unid $^{c}$ & \\
\hline 2001 & St. James & Nursery & 6 & 6 & 6 & 6 & 1 & 3 & 0 & 2 & 0 \\
\hline 2001 & St. James & Outfield trial & 18 & 10 & 6 & 18 & 2 & 10 & 0 & 6 & 0 \\
\hline 2001 & Terrebonne & Research farm & 11 & 11 & 6 & 9 & 1 & 6 & 0 & 2 & 2 \\
\hline 2002 & Assumption & Production farm & 25 & 5 & 2 & 24 & 4 & 20 & 0 & 0 & 1 \\
\hline 2002 & Iberia & Outfield trial & 62 & 13 & 5 & 61 & 0 & 61 & 0 & 0 & 1 \\
\hline 2002 & Iberville & Research farm & 89 & 19 & 17 & 84 & 3 & 67 & 5 & 9 & 5 \\
\hline 2002 & Lafourche & Outfield trial & 28 & 6 & 2 & 25 & 0 & 25 & 0 & 0 & 3 \\
\hline 2002 & St. James & Nursery & 78 & 15 & 11 & 76 & 5 & 38 & 0 & 33 & 2 \\
\hline 2002 & St. James & Outfield trial & 56 & 12 & 6 & 53 & 20 & 31 & 2 & 0 & 3 \\
\hline 2002 & Terrebonne & Outfield trial & 12 & 4 & 1 & 9 & 0 & 9 & 0 & 0 & 3 \\
\hline 2002 & Terrebonne & Nursery & 5 & 2 & 1 & 5 & 0 & 5 & 0 & 0 & 0 \\
\hline 2003 & Avoyelles & Nursery & 12 & 4 & 4 & 11 & 0 & 11 & 0 & 0 & 1 \\
\hline 2003 & Iberia & Outfield trial & 40 & 8 & 3 & 37 & 0 & 34 & 0 & 0 & 3 \\
\hline 2003 & Iberia & Nursery & 6 & 2 & 2 & 4 & 0 & 4 & 0 & 0 & 2 \\
\hline 2003 & Iberville & Research farm & 91 & 22 & 21 & 83 & 23 & 54 & 8 & 5 & 8 \\
\hline 2003 & Lafayette & Nursery & 10 & 2 & 2 & 10 & 0 & 9 & 0 & 1 & 0 \\
\hline 2003 & Lafourche & Outfield trial & 18 & 4 & 2 & 15 & 0 & 15 & 0 & 0 & 3 \\
\hline 2003 & St. James & Nursery & 84 & 17 & 13 & 75 & 1 & 42 & 2 & 33 & 9 \\
\hline 2003 & St. James & Outfield trial & 32 & 8 & 5 & 29 & 12 & 17 & 1 & 1 & 3 \\
\hline 2003 & Terrebonne & Outfield trial & 10 & 2 & 1 & 7 & 0 & 7 & 0 & 0 & 3 \\
\hline 2001 & Total & $\ldots$ & 35 & $\ldots$ & $\ldots$ & $33(94)$ & $4(11)$ & $19(54)$ & $0(0)$ & $10(29)$ & $2(6)$ \\
\hline 2002 & Total & $\ldots$ & 355 & $\ldots$ & $\ldots$ & $337(95)$ & $32(9)$ & $256(72)$ & $7(2)$ & 42 (12) & $18(5)$ \\
\hline 2003 & Total & $\ldots$ & 303 & $\ldots$ & $\ldots$ & $271(90)$ & 36 (12) & $193(64)$ & $10(3)$ & 40 (13) & 32 (11) \\
\hline Overall & Total & $\ldots$ & 693 & $\ldots$ & $\ldots$ & $641(92)$ & 72 (10) & $468(68)$ & $17(2)$ & 92 (13) & $52(8)$ \\
\hline
\end{tabular}

a Incidence of Sorghum mosaic virus (SrMV) strains based on restriction fragment length polymorphism analysis of reverse-transcriptase polymerase chain reaction (RT-PCR) product.

b Number of samples positive for SrMV based on RT-PCR.

${ }^{c}$ Unid = unidentified strain of SrMV.

${ }^{\mathrm{d}}$ Number of samples negative for Sugarcane mosaic virus and SrMV based on RT-PCR. 
homogenized in a microfuge tube containing $1 \mathrm{ml}$ of cetyltrimethylammonium bromide (CTAB) extraction buffer (2\% CTAB, $1.4 \mathrm{M} \mathrm{NaCl}, 20 \mathrm{mM}$ EDTA, 100 $\mathrm{mM}$ Tris- $\mathrm{HCl}[\mathrm{pH} 8.0]$, and $2 \mu \mathrm{l}$ of mercaptoethanol) and a 4.5-mm-diameter steel bead by vigorously shaking the tube using a Mini-Bead-Beater (BioSpec Products, Inc., Bartleville, OK) for $1 \mathrm{~min}$. The tissue homogenate was incubated for $30 \mathrm{~min}$ at $60^{\circ} \mathrm{C}$. The nucleic acids were extracted once by mixing with $0.75 \mathrm{ml}$ of chloroform:isoamyl alcohol (24:1), centrifuging at $8,000 \times g$ for $10 \mathrm{~min}$ at $4^{\circ} \mathrm{C}$, and transferring $600 \mu \mathrm{l}$ of the upper aqueous phase to a new microfuge tube containing $500 \mu \mathrm{l}$ of cold isopropyl alcohol. The mixture was incubated at $-20^{\circ} \mathrm{C}$ for at least $1 \mathrm{~h}$ (but could be held overnight) and centrifuged for $15 \mathrm{~min}$ at $12,000 \times \mathrm{g}$, and the resulting pellet was washed with $70 \%$ ethanol plus $10 \mathrm{mM}$ sodium acetate. The mixture was centrifuged again for $10 \mathrm{~min}$ at $12,000 \times g$ and the supernatant was discarded. Nucleic acid pellets were dried in a DNA 120 SpeedVac System (Savant Instruments, Inc., Holbrook, NY) and resuspended in $200 \mu \mathrm{l}$ of sterile distilled water.

The virus strains causing mosaic in the sampled plants were identified using a modification of the RT-PCR-based RFLP protocol described by Yang and Mirkov (21). For the reverse transcription phase, 1 $\mu \mathrm{l}$ of sample, $0.25 \mu \mathrm{l}$ of reverse primer (SCMV-R3 for SCMV or SrMV-R3 for SrMV; 21) (60 $\mu \mathrm{M}$ stock), and $0.25 \mu \mathrm{l}$ of water were placed in a $0.5-\mathrm{ml}$ thin-wall microtube. Samples were tested for both SCMV and SrMV. The mixture was overlaid with mineral oil, heated in a ThermoCycler 9700 (Perkin Elmer, Foster City, $\mathrm{CA})$ at $95^{\circ} \mathrm{C}$ for $5 \mathrm{~min}$ for denaturing, and then quenched on ice. While keeping samples on ice, $8.5 \mu$ l of reverse-transcriptase solution was added. The solution consisted of $2.0 \mu \mathrm{l}$ of $\mathrm{MgCl}_{2}(25 \mathrm{mM}), 1.0 \mu \mathrm{l}$ of $10 \times$ PCR buffer, $1.0 \mu \mathrm{l}$ of dGTP $(10 \mu \mathrm{M}), 1.0 \mu \mathrm{l}$ of dCTP $(10 \mathrm{mM}), 1.0 \mu \mathrm{l}$ of dATP (10 $\mathrm{mM}), 1.0 \mu \mathrm{l}$ of dTTP $(10 \mathrm{mM}), 0.5 \mu \mathrm{l}$ of $\mathrm{H}_{2} \mathrm{O}, 0.5 \mu \mathrm{l}$ of RNAse inhibitor $(20 \mathrm{U} / \mu \mathrm{l})$ (Perkin Elmer), and $0.5 \mu \mathrm{l}$ of moloney Murine leukemia virus reverse transcrip-

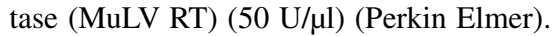
Reverse transcription was performed at $37^{\circ} \mathrm{C}$ for $15 \mathrm{~min}$, then $99^{\circ} \mathrm{C}$ for $5 \mathrm{~min}$, and held at $4^{\circ} \mathrm{C}$ until the next step was performed. With the tube on ice, $40 \mu \mathrm{l}$ of PCR reagents was added. PCR reagents were $4.0 \mu \mathrm{l}$ of $\mathrm{MgCl}_{2}(25 \mathrm{mM}), 4.0 \mu \mathrm{l}$ of $10 \times$ PCR buffer, $31.5 \mu$ of $\mathrm{H}_{2} \mathrm{O}, 0.25 \mu \mathrm{l}$ of Amplitaq DNA polymerase (5 U/ $\mu \mathrm{l})$ (Perkin Elmer), and $0.25 \mu \mathrm{l}$ of SCMV-F3 primer for SCMV or SrMV-F3 for SrMV (60 $\mu \mathrm{M}$ stock; 21). The PCR program was $95^{\circ} \mathrm{C}$ for $5 \mathrm{~min}, 60^{\circ} \mathrm{C}$ for $1 \mathrm{~min}, 72^{\circ} \mathrm{C}$ for $10 \mathrm{~min}$, and $94^{\circ} \mathrm{C}$ for $1 \mathrm{~min}$; followed by 39 cycles of $94^{\circ} \mathrm{C}$ for $1 \mathrm{~s}, 60^{\circ} \mathrm{C}$ for $1 \mathrm{~s}$, and $72^{\circ} \mathrm{C}$ for $30 \mathrm{~s}$; and final extension at $72^{\circ} \mathrm{C}$ for $5 \mathrm{~min}$. Upon completion, $5 \mu \mathrm{l}$ of the RT-PCR sample were mixed with $1 \mu$ of
$6 \times$ gel loading buffer, which was electrophoresed in a $2 \%$ agarose/Synergel binary gel containing ethidium bromide $(0.5$ $\mu \mathrm{g} / \mathrm{ml}$ ) for $1 \mathrm{~h}$ and visualized under UV light. Images were captured with NucleoVision Image Workstation (NucleoTech Corp. San Mateo, CA). Once the identity of the virus was determined using RTPCR, RFLP was conducted to determine the strain of the virus.

For RFLP, $30 \mu \mathrm{l}$ of the remaining RTPCR products was precipitated from the aqueous phase by the addition of $2.25 \mu \mathrm{l}$ of $4 \mathrm{M}$ sodium acetate and $96.75 \mu \mathrm{l}$ of ethanol. The pellets were washed two times with $70 \%$ ethanol and dissolved in $15 \mu \mathrm{l}$ of distilled water. The RT-PCR products from SCMV were digested with restriction enzymes ApoI and $X b a \mathrm{I}$ and the RT-PCR products from SrMV with $\mathrm{HgaI}$ using the protocol of Yang and Mirkov (21). The digestion products were analyzed by electrophoresis through 2\% agarose/Synergel binary gel.

To verify the pathogenicity of SrMV isolates that differed from strains $\mathrm{H}$, I, or $M$ by RT-PCR-based RFLP analysis, healthy plants were inoculated with juice extracted from the leaves of the source plant as described by Grisham (7). Pathogen identification was made using the RTPCR-based RFLP protocol upon appearance of mosaic symptoms.

Cloning and sequencing of the RTPCR product from the unidentified isolate. The RT-PCR product from the unidentified isolate was gel-purified using the
QIAquick Gel Extraction Kit (Qiagen Inc., Chatsworth, CA) and cloned into the pCR 2.1 plasmid vector using Original TA Cloning Kit (Invitrogen Corp., Carlsbad, CA) following the manufacturer's protocol. Recombinant pCR 2.1 clones were chosen based on EcoRI restriction analysis. Three clones were sequenced using the BigDye Sequencing Kit (v3.0) on automatic DNA Sequencer ABI PRISM 3100 (Applied Biosystems, Foster City, CA). Sequencing files were processed by the SeqMan software (DNASTAR, Inc., Madison, WI). Corresponding DNA sequences of SrMV strains M (U57360), H (U57358), and I (U57359) were downloaded from GenBank. DNA sequence alignment, homology assessment, and restriction analysis were conducted using the DNAMAN software (Lynnon BioSoft, Vaudreuil, Quebec, Canada).

\section{RESULTS AND DISCUSSION}

An RT-PCR product was successfully amplified from corresponding isolates of $\operatorname{SCMV}(\mathrm{A}, \mathrm{B}$, and D) and SrMV (H, I, and $\mathrm{M})$ using the primers and RT-PCR protocol of Yang and Mirkov (21). No product was produced from the water (negative) control. Restriction digestions of the RT-PCR products from strains $\mathrm{A}, \mathrm{B}$, and $\mathrm{D}$ of SCMV with ApoI and XbaI (not shown) and strains $\mathrm{H}$, I, and $\mathrm{M}$ of SrMV with HgaI (Fig. 1, lanes 7, 8, and 9) produced banding patterns that were consistent with those reported by Yang and Mirkov (21). The yields of the Hga1-restriction frag-

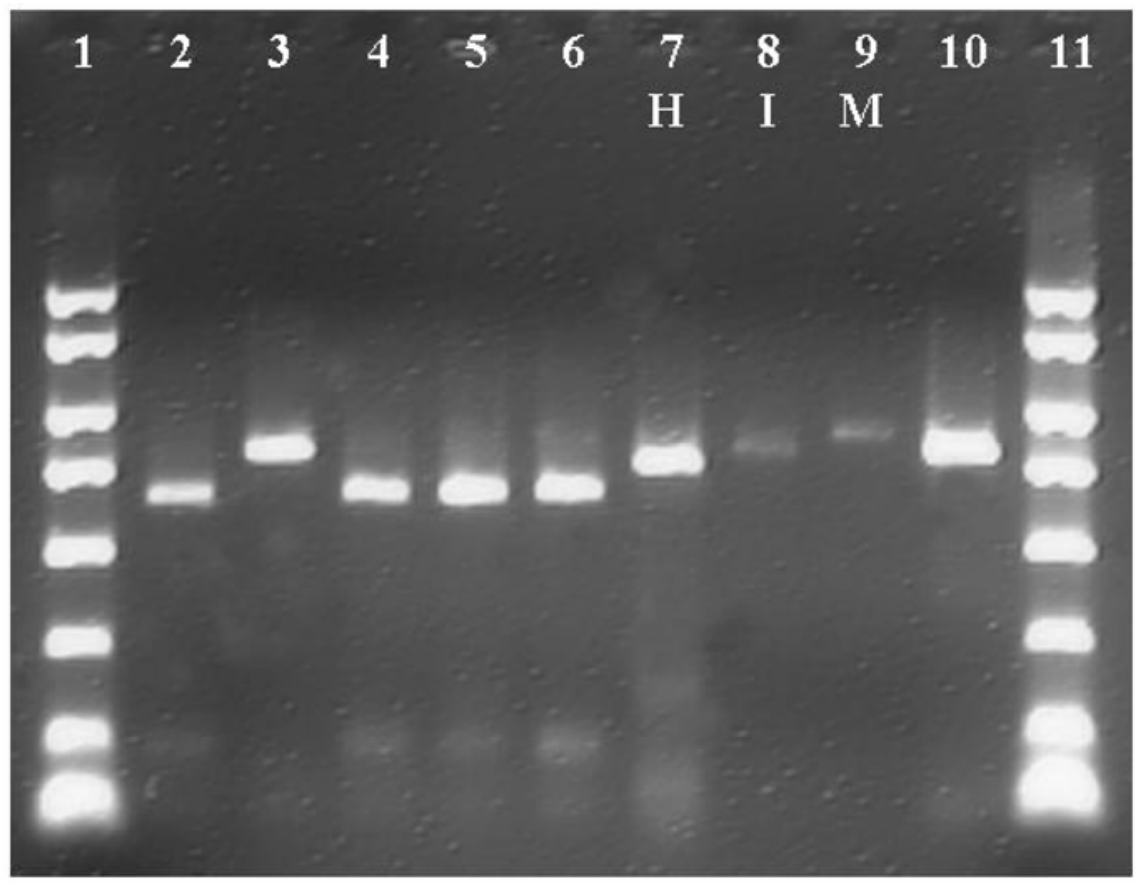

Fig. 1. Ethidium bromide-stained $\mathrm{HgaI}$ restriction enzyme digested DNA fragments of amplified reverse-transcription polymerase chain reaction products from strains of Sorghum mosaic virus. Lanes 1 and 11, DNA size markers (top to bottom: 2,000, 1,500, 1,000, 750, 500, 300, 150, and 50 bp); lane 2, unidentified strain (field); lane 3, strain I recovered from cv. B96-96 (field) ; lanes 4, 5, and 6, unidentified strain (greenhouse); lane 7, strain H (control); lane 8, strain I (control); lane 9, strain M (control); and lane 10, strain I recovered from self clone no. 99 from LCP 85-384 (greenhouse). 
ments from strains I and $\mathrm{M}$ were relatively lower than those of strain $\mathrm{H}$ and other samples (Fig. 1) because we did not calibrate and adjust the quantities of the RTPCR products prior to performing the restriction analyses.

The SrMV-specific primers, SrMV F3 and SrMV R3, amplified an RT-PCR product from 641 (92\%) of 693 leaf samples showing mosaic symptoms. However, none of the leaf samples produced an RT-PCR product when SCMV-specific primers SCMV F3 and SCMV R3 were used (Table 1). The cause of mosaic symptoms in
$52(8 \%)$ of the plants sampled could not be determined because no RT-PCR product was produced with either SCMV- or SrMV-specific primers (Table 1). Other diagnostic protocols are needed to determine the cause of mosaic symptoms in these plants.

A decision was made not to collect samples from asymptomatic plants because prior assays of asymptomatic plants using host differentials, serological tests, and RTPCR had failed to detect SCMV or SrMV (unpublished). Given the possibility that an asymptomatic virus infection may serve as a reservoir of inoculum, detection probably will require a more sensitive diagnostic protocol than the one used in this study.

RFLP analysis of the RT-PCR products showed that, among 641 plants that tested positive for SrMV, strain I was the predominant strain $(68 \%)$ in all three years: 2001 (54\%), 2002 (72\%), and 2003 (64\%) (Table 1). Furthermore, strain I was the only strain recovered among the samples testing positive for SrMV at the three outfield trial locations in Iberia, Lafourche, and Terrebonne Parishes during the 2002 and 2003 surveys. It also was the only

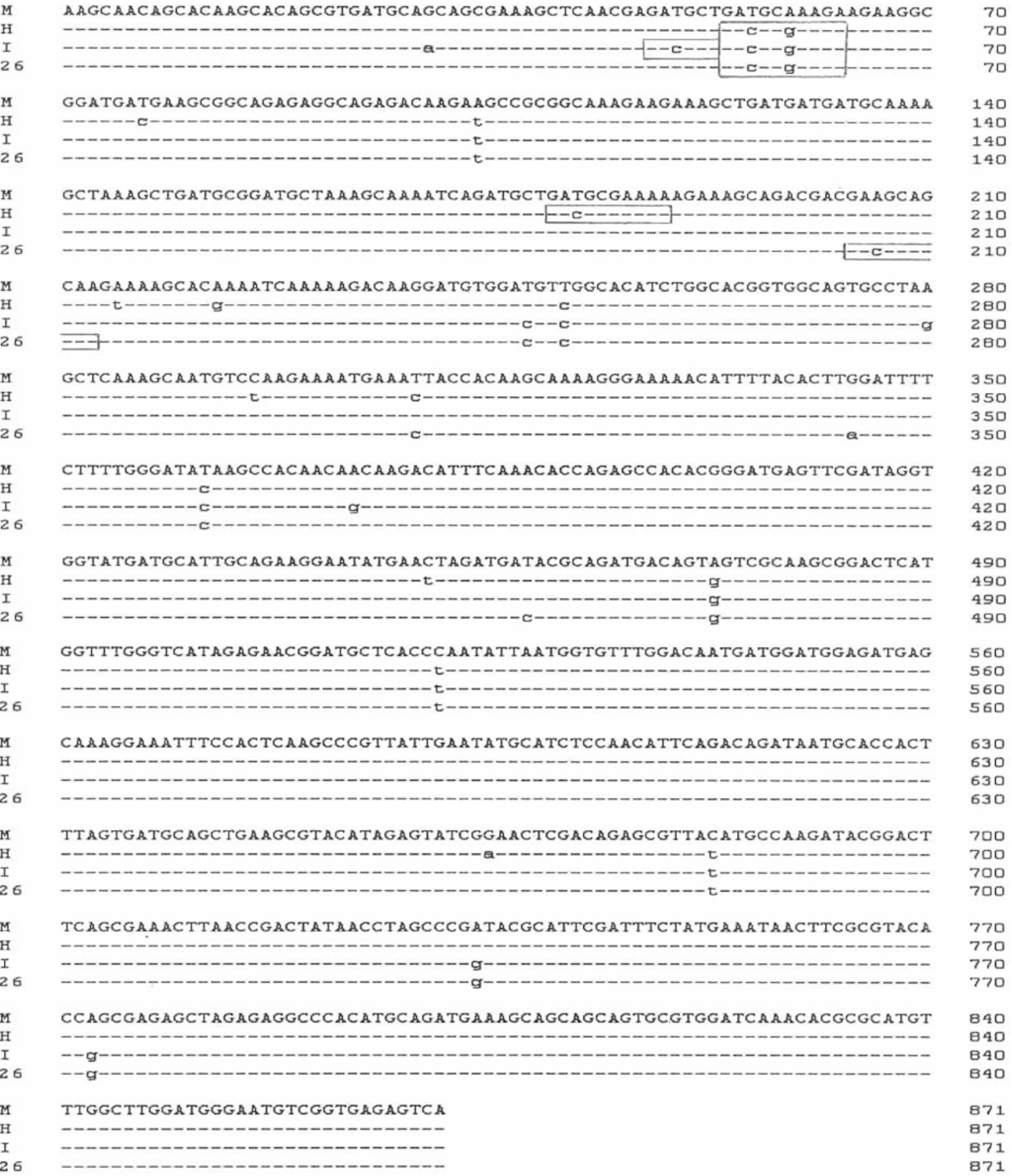

Fig. 2. Alignment of the DNA sequence of amplified reverse-transcription polymerase chain reaction product from the unidentified Sorghum mosaic virus (SrMV) strain (labeled as 26) (EF078962) with the corresponding sequences of SrMV strains M (U57360), H (U57358), and I (U57359) using the DNAMAN software (Lynnon BioSoft, Vaudreuil, Quebec, Canada). Recognition sites (GACGCNNNNN) of the restriction enzyme HgaI are boxed. 
strain recovered at the three nursery locations in Avoyelles, Iberia, and Lafayette Parishes. This was in contrast to the results from surveys conducted between 1978 and 1992 (7) and additional unpublished surveys conducted between 1993 and 1995, in which strain H of SrMV was the predominant virus. Between 1978 and 1995, strain $\mathrm{H}$ was recovered from more than $90 \%$ of the plants tested, except in 1980, when it was recovered from $87 \%$ of the plants (7; unpublished).

The second most frequently recovered strain among samples in 2001, 2002, and 2003 was strain $\mathrm{H}$, with recovery rates of 11,9 , and $12 \%$, respectively. The location with the highest frequency of strain $\mathrm{H}$ recovery was the outfield trial in St. James Parish where, in 2002 and 2003, it was recovered from 36 and $38 \%$ of the samples, respectively. Strain M of SrMV was identified as causing mosaic in only 17 (2\%) plants (Table 1).

When RFLP analysis was performed on the RT-PCR products derived from the SrMV-specific primer set (21), $13 \%$ of the samples produced banding patterns that did not match the RFLP patterns for strains $\mathrm{H}$, I, or $\mathrm{M}$ as described by Yang and Mirkov (21) (Table 1; Fig. 1, lane 2 as one example). This observation was confirmed when leaves were recollected from the same plots, homogenized, and used to mechanically inoculate new host plants in the greenhouse. When the leaves of the inoculated plants showing mosaic were analyzed by the RT-PCR-based RFLP protocol, the same banding pattern was observed (Fig. 1, lanes 4, 5, and 6).

When the DNA sequence of the RT-PCR product from the unidentified strain (Fig. 1, lane 2) (EF078962) was aligned with the corresponding sequences of SrMV strains M (U57360), H (U57358), and I (U57359), the sequence was $98.3,98.5$, and $99.1 \%$ identical to strains $\mathrm{M}, \mathrm{H}$, and $\mathrm{I}$, respectively (Fig. 2). There was no $\mathrm{Hgal}$ restriction site (GACGCNNNNN/) for strain M, although a unique $H g a 1$ restriction site was located within nucleotides 48 to 57 for strain I, 180 to 189 for strain $\mathrm{H}$, and 204 to 213 for the unidentified strain, respectively. An additional Hgal restriction site was found between nucleotides 54 to 63 that was common to strains $\mathrm{H}, \mathrm{I}$, and the unidentified strain. Based on this analysis, the predicted size of the largest $\mathrm{Hgal}$ restriction fragment from the RT-PCR product was $871 \mathrm{bp}$ for strain M, $808 \mathrm{bp}$ for strain I, $682 \mathrm{bp}$ for strain $\mathrm{H}$, and $658 \mathrm{bp}$ for the unidentified strain.

Among the 145 plots sampled in 2002 and 2003, 96 plots (66\%) were infected with a single virus strain, 43 plots $(30 \%)$ were co-infected with two virus strains, and the remaining 6 plots $(4 \%)$ were coinfected with three virus strains. Strain $M$ was found only in plots where at least one other strain of SrMV was found. Among the 693 plants tested, $14(2 \%)$ were in- fected with multiple SrMV strains (Table 2). Twelve plants were co-infected with two SrMV strains and two plants were coinfected with three SrMV strains. In the survey of virus strains conducted in Louisiana between 1978 and 1992, approximately $4 \%$ of the plants were found to be co-infected with two SrMV strains, except for one plant that was co-infected with all three identified SrMV strains (H, I, and M; 7). Koike and Gillaspie (11) suggested that mixtures of strains might become unstable and one strain would become dominant.

In this study, no leaf samples tested positive for SCMV when analyzed with RT-PCR using SCMV-specific primers. SCMV has not been reported on commercial sugarcane in Louisiana for over 30 years $(5,7)$. The use of resistant cultivars eliminated the effect of mosaic on the Louisiana sugarcane industry in the 1940s and early 1950s and, possibly, resulted in the disappearance of SCMV. However, with the appearance of SrMV strain H in 1956, the disease again became widespread. During the 1980s and the first half of the 1990s, all major cultivars grown in Louisiana were susceptible or moderately susceptible to mosaic caused by SrMV strain H. This situation rapidly changed in 1993 with the release of cv. LCP 85-384 and its widespread acceptance by Louisiana sugarcane growers. This cultivar occupied $88 \%$ of the sugarcane production area in 2003 (13). Although no mosaic has been found on LCP 85-384, the Louisiana sugarcane industry would become vulnerable to the rapid development of mosaic if a new strain or virus overcame the resistance of this cultivar.

In the production fields in Assumption Parish (Table 1, year 2002), the mosaicsusceptible cv. CP 65-357 was infected with SrMV strain I, and the moderately resistant cv. HoCP 85-845 was infected with SrMV strain H. In earlier surveys, when CP 65-357 was a major cultivar (7; unpublished), the strain most commonly recovered from this cultivar was SrMV strain H. In this survey, cv. HoCP 85-845 also was sampled at two other locations. Among plants of cv. HoCP 85-845 with mosaic symptoms in the outfield trials in Iberia and St. James Parishes, 22 of the 27 plants were infected with SrMV strain I, 3 with SrMV strain H, 1 with SrMV strain $M$, and 1 with the unidentified strain of SrMV (Fig. 1, lane 2). One symptomatic plant collected from the St. James Parish outfield test in 2003 was co-infected with three strains (H, I, and M; Table 2), and another symptomatic plant tested negative for both SrMV and SCMV.

In all, 134 plants of CP 70-321 showing mosaic symptoms were sampled at the four outfield trials. SrMV strain I was detected in 119 plants, whereas neither SCMV nor SrMV were identified in 15 other plants. During the earlier surveys (7; unpublished), CP 70-321 also was a major cultivar and, as with CP 65-357, SrMV strain $\mathrm{H}$ was the most commonly identified virus from infected plants. Although strain I was the only strain of SrMV found in plants of CP 70-321 from the outfield trials, strain $\mathrm{H}$ was recovered from plants in two plots of CP 70-321 sampled at the experiment station located in Iberville Parish.

The reaction of advanced candidate $\mathrm{cv}$. HoCP 97-606 to mosaic was one of the reasons for initiating this survey. Mosaic was not observed in this cultivar during the early stages of testing. However, mosaic was observed when the cultivar was advanced to the outfield trials. At the nursery location in St. James Parish, an unidentified SrMV strain was found infecting HoCP 97-606. However, at the outfield location in St. James Parish, SrMV strain $\mathrm{H}$ was recovered from this cultivar in 2002 and strains $\mathrm{H}$ and $\mathrm{I}$ in 2003. At the outfield tests in Iberia Parish, all HoCP 97-606 samples were infected with SrMV strain I.

Most cultivars in the experimental trials are in the latter stages of testing before being considered for release to the sugarcane industry. At this stage of the cultivar development program, cultivars have been

Table 2. Sugarcane plants infected with multiple strains of Sorghum mosaic virus (SrMV)

\begin{tabular}{llllll}
\hline & \multicolumn{2}{c}{ Location } & & \\
\cline { 2 - 3 } Year & Parish & \multicolumn{1}{c}{ Type } & & Cultivar & Strains of SrMV \\
\hline 2002 & St. James & Nursery & & HoCP 98-743 & I, M \\
2002 & St. James & Nursery & & HoCP 98-749 & I, Unid \\
2003 & Iberville & Research farm & & HoCP 00-900 & I, H \\
2003 & Iberville & Research farm & & HoCP 00-900 & I, H \\
2003 & Iberville & Research farm & & HoCP 00-958 & I, M \\
2003 & Iberville & Research farm & & HoCP 00-958 & I, M \\
2003 & Iberville & Research farm & & HoCP 00-958 & I, M \\
2003 & Iberville & Research farm & & HoCP 01-556 & H, I, Unid \\
2003 & St. James & Nursery & & HoCP 97-621 & M, Unid \\
2003 & St. James & Nursery & & HoCP 97-621 & I, Unid \\
2003 & St. James & Nursery & & HoCP 97-641 & I, Unid \\
2003 & St. James & Nursery & & HoCP 97-641 & I, Unid \\
2003 & St. James & Nursery & & HoCP 98-741 & M, Unid \\
2003 & St. James & Outfield Test & HoCP 85-845 & H, I, M \\
\hline
\end{tabular}

a Based on restriction fragment length polymorphism analysis of reverse-transcriptase polymerase chain reaction product. Unid $=$ unidentified strain of SrMV. 
exposed to a number of years of natural infection and those expressing mosaic symptoms have been eliminated. In Louisiana, the average time from crossing elite parents to the release of a cultivar to the sugarcane industry is 14 years. The candidate cultivars in the off-station nurseries are in their seventh to tenth year of testing and those in the outfield trials are in their ninth through twelfth year of testing. SrMV strain $\mathrm{H}$ was the predominant strain causing mosaic at the time most of the cultivars sampled in this survey were undergoing early stages of selection and advancement (7; unpublished). The shift in which a strain of mosaic-causing virus becomes predominant may provide some explanation of why a cultivar has been advanced this far into the cultivar development program without being eliminated for susceptibility to mosaic.

Although the potential new strain of SrMV has not been demonstrated to infect the current resistant cultivars being grown in Louisiana, its discovery in this survey demonstrates the genetic variability and adaptability of the virus that causes mosaic in sugarcane. The inability to demonstrate that neither SCMV nor SrMV was the cause of the mosaic in some plants (Table 1) suggests that another pathogen may cause mosaic-like symptoms. Further studies are needed to describe the cause of these disease symptoms.

When SrMV strain H appeared, efforts were initiated to incorporate new sources of resistance to mosaic from wild relatives of sugarcane $(6,9)$. Success of this program has been realized in the release of several cultivars that include LCP 85-384 (15), the current leading cultivar in Louisiana. Three additional mosaic-resistant cultivars recently were released: HoCP 96-540 in 2002 (19) and Ho95-988 (3) and L 97-128 (4) in 2004. If a new strain of virus appeared that could overcome the resistance of LCP 85-384, HoCP 96-540 and L 97128 also would be vulnerable because both cultivars are the progeny of LCP 85-384. Sugarcane breeders and pathologists continue to find new sources of resistance to mosaic $(9,12)$; therefore, an awareness of the genetic diversity of the pathogen is needed when screening new germ plasm.

\section{ACKNOWLEDGMENTS}

This project was partially funded by grower/processor check-off funds administrated by the American Sugar Cane League of the USA, Inc. We thank K. Warnke, R. Gonzalez, Q. Wei, L. Lomax, and S. Bibbins for technical assistance; and E. Dufrene for sample identification and collection.

\section{LITERATURE CITED}

1. Abbott, E. V. 1961. Mosaic. Pages 407-430 in: Sugar Cane Diseases of the World. Vol. 1. J. P. Martin, E. V. Abbott, and C. G. Hughes, eds. Elsevier, Amsterdam.

2. Abbott, E. V., and Tippett, R. L. 1966. Strains of sugarcane mosaic virus. U. S. Dep. Agric. Tech. Bull. 1340.

3. Anonymous. 2004. Notice of release of sugarcane variety Ho 95-988. Sugar Bull. 82(9):1415.

4. Anonymous. 2004. Notice of release of sugarcane variety L 97-128. Sugar Bull. 82(9):16-17.

5. Breaux, R. D., and Koike, H. 1978. Problems and progress in breeding sugarcane for mosaic resistance in Louisiana's subtropical environment. Proc. Int. Soc. Sugar Cane Technol. 16:425-432.

6. Dunckelman, P. H., and Breaux, R. D. 1969. Evaluation of germplasm in USDA sugarcane for mosaic resistance in Louisiana's subtropical environment. Proc. Int. Soc. Sugar Cane Technol. 13:888-892.

7. Grisham, M. P. 1994. Strains of sorghum mosaic virus causing sugarcane mosaic in Louisiana. Plant Dis. 78:729-732.

8. Grisham, M. P. 2000. Mosaic. Pages 249-254 in: A Guide to Sugarcane Diseases. P. Rott, R. A. Bailey, J. C. Comstock, B. J. Croft, and A. S. Saumtally, eds. CIRAD and ISSCT, Montpellier, France.

9. Grisham, M. P., Burner, D. M., and Legendre, B. L. 1992. Resistance to the H strain of sugarcane mosaic virus among wild forms of sugarcane and relatives. Plant Dis. 76:360-362.

10. Koike, H., and Gillaspie, A. G., Jr. 1976. Strain $\mathrm{M}$, a new strain of sugarcane mosaic virus.
Plant Dis. Rep. 60:50-54.

11. Koike, H., and Gillaspie, A. G. Jr. 1989. Mosaic. Pages 301-322 in: Diseases of Sugarcane. Major Diseases. C. Ricaud, B. T. Egan, A. G. Gillaspie, Jr., and C. G. Hughes, eds. Elsevier Science Publishers, Amsterdam.

12. Legendre, B. L. 1989. Use of feral germplasm for sugarcane improvement in Louisiana. Proc. Int. Soc. Sugar Cane Technol. 20:883-891.

13. Legendre, B. L., and Gravois, K. A. 2005. The 2004 Louisiana sugarcane variety survey. Sugar Bull. 83(9):15-21.

14. McKern, N. M., Shukla, D. D., Toler, R. D., Jensen, S. G., Tosic, M., Ford, R. E., Leon, O., and Ward, C. W. 1991. Confirmation that the sugarcane mosaic virus subgroup consists of four distinct potyviruses by using peptide profiles of coat proteins. Phytopathology 81:10251029.

15. Milligan, S. B., Martin, F. A., Bischoff, K. P., Quebedeaux, Dufrene, E. O., Quebedeaux, K L., Hoy, J. W., Reagan, T. E., Legendre, B. L., and Miller, J. D. 1994. Registration of 'LCP 85-384' sugarcane. Crop Sci. 34:819-820.

16. Shukla, D. D., Tosic, M., Jilka, J., Ford, R. E., Toler, R. W., and Langham, M. A. C. 1989. Taxonomy of potyviruses infecting maize, sorghum and sugarcane in Australia and the United States as determined by reactivities of polyclonal antibodies directed towards virusspecific N-termini of coat proteins. Phytopathology 79:223-229.

17. Smith, G. R., and Van de Velde, R. 1994. Detection of sugarcane mosaic virus and Fiji disease virus in diseased sugarcane using the polymerase chain reaction. Plant Dis. 78:557561.

18. Summers, E. M., Brandes, E. W., and Rands, R. D. 1948. Mosaic of sugarcane in the United States with special reference to strains of the virus. U. S. Dep. Agric. Tech. Bull. 955.

19. Tew, T. L., White, W. H., Legendre, B. L., Grisham, M. P., Dufrene, E. O., Garrison, D. D., Veremis, J. C., Pan, Y.-B., Richard, E. P., Jr., and Miller, J. D. 2005. Registration of 'HoCP 96-540' Sugarcane. Crop Sci. 45:785786.

20. Tippett, R. L., and Abbott, E. V. 1968. A new strain of sugarcane mosaic virus in Louisiana. Plant Dis. Rep. 53:449-451.

21. Yang, Z. N., and Mirkov, T. E. 1997. Sequence and relationships of sugarcane mosaic and sorghum mosaic virus strains and development of RT-PCR-based RFLPs for strain discrimination. Phytopathology 87:932-939. 